\title{
Metadiscursive Markers and Text Genre: A Metareview
}

\author{
Miguel Cuevas-Alonso * and Carla Míguez-Álvarez $\mathbb{C}$
}

\author{
Department of Spanish Linguistics, Campus Lagoas Marcosende, University of Vigo, 36310 Vigo, Spain; \\ camiguez@uvigo.es \\ * Correspondence: miguel.cuevas@uvigo.es
}

Citation: Cuevas-Alonso, M.; Míguez-Álvarez, C. Metadiscursive Markers and Text Genre: A Metareview. Publications 2021, 9, 56 https://doi.org/10.3390/ publications 9040056

Academic Editor: Lauren Brittany Collister

Received: 8 September 2021

Accepted: 29 November 2021

Published: 3 December 2021

Publisher's Note: MDPI stays neutral with regard to jurisdictional claims in published maps and institutional affiliations.

Copyright: (c) 2021 by the authors. Licensee MDPI, Basel, Switzerland. This article is an open access article distributed under the terms and conditions of the Creative Commons Attribution (CC BY) license (https:// creativecommons.org/licenses/by/ $4.0 /)$.

\begin{abstract}
Given the interest in the study of metadiscourse as the communication of ideas and the way people use language in different communicative situations, this paper attempted to find the degree of confluence between metadiscourse markers from different studies and to show how patterns of metadiscourse analysis based on various written genres can be applied to a wider range. The mean values for the frequency of marker use and their respective deviations were determined by comparing a significant number of studies on metadiscourse elements. To ensure comparability, those following Hyland's model were chosen. The units of analysis were grouped into two broad categories based on discursive characteristics: Academic genres (research articles, theses, and textbooks) and non-academic genres, which included documents ranging from newspaper editorials or opinion columns to Internet texts and other forms of digital communication. The results of our study highlight that the disparity in interactive markers between academic and non-academic texts is relatively small. This difference has been identified by previous studies, and it is confirmed herein that the difference may be related to the use of academic language, the topic, or the object of study. In contrast, the mean values of the interactive markers in non-academic texts are considerably higher than those in academic texts. At the same time, the texts seem to be organised along two axes (interactional and interactive) in distinct areas. Despite our initial assumptions that the data would be subject to individual variations, that differences would be found between different sections of the same genre within the same academic discipline, and that the results would vary if certain texts were added or excluded, we observed certain trends in the behaviour of the documents, although it prevailed that, within each category, the texts should be studied individually.
\end{abstract}

Keywords: text genre; metadiscourse markers; interactive markers; interactional markers; metareview

\section{Introduction \\ 1.1. Definitions}

In the context of this study, we understand language as a tool for social interaction and communication [1]. Given this definition, one can easily recognise that the genre, metadiscourse, and research concerning these two concepts are essential for our understanding of the concept of communication [2]. Larsen-Freeman et al. [3] aptly noted the difficulty of defining discourse in a way that captures its complexity. Schiffrin, Tannen, and Hamilton [4] referred to discourse as being understood through three fundamental categories: (1) As that which extends beyond the sentence, (2) as language use, or (3) as a social practice that includes non-linguistic aspects: "Metadiscourse embodies the idea that communication is more than just the exchange of information, goods or services, but also involves the personalities, attitudes, and assumptions of those who are communicating" [5].

Metadiscourse is crucial to text creation because markers help to establish relationships between the speaker/writer, the listener/reader, the socio-cultural context, and the specific communicative situation $[5,6]$. In one respect, metadiscourse guides how a message is interpreted, because it also reflects the linguistic expression of sociocultural reality. This allows us to clarify essential details such as what the author is trying to say, his opinion 
on the topic, his arguments, and the content of the text. Of course, when we understand language use more deeply, we can use our knowledge to improve the quality of our own writing. Adding these types of words can help us express ourselves better in our non-native language, help others understand what we have written, and potentially improve our academic performance.

Metadiscourse markers are words or phrases that help connect and organise text, express an attitude, provide evidence, connect the reader to the writer, and ensure that the text "flows" from one idea to the next. This term has been studied extensively by numerous linguists, including Ken Hyland and Annelie Ädel [7]. Hyland [8] showed that metadiscourse essentially refers to how we use language out of consideration for our readers or listeners "based on our estimation of how we can best help them process and understand what we are saying..."

In this respect, according to Vande Kopple [9], metadiscourse is "discourse about discourse or communication about communication." Meanwhile, Hyland [5] referred to it as textual elements used to organise text, to indicate the writer's attitude, and to make the intended message more effective and easier for the addressee/reader to understand. Metadiscourse also includes authorial presence without the addition of propositional information. In a certain sense, metadiscourse is the "author's intrusion into the discourse, either explicitly or non-explicitly, to direct the reader rather than inform" [10]. Therefore, it refers not to the contents of the text but to the speaker/writer, the listener/reader, or the text.

With regard to the elements encompassed by metadiscourse, Ädel [7] distinguished between a broad view of metadiscourse, which defines as each and every linguistic resource that organises the text or contributes to communicating the author's opinions, and a narrower view, which conceptualises metadiscourse exclusively as the linguistic elements that fulfil a textual function. This narrow view is excessively constrictive and overlooks the interpersonal essence of metadiscourse, as Wei et al. [11] noted in their literature review.

In this theoretical framework, we must emphasise that analogously to how the definition of a "metadiscursive marker" is not unitary, neither are the ways that the term is classified [12,13].

\subsection{Models}

In her discussion of Williams's and Meyer's classifications, Crismore [10] classified metadiscourse into two general categories: Informational, the aspects of discourse intended to improve the reader's understanding, and attitudinal, those that reveal the author's attitude towards the content or structure of the text or towards the listener/reader. Crismore further divided each category into several subtypes (see Figure 1).

According to Vande Kopple [9], metadiscourse can be divided into two vague, functionally overlapping categories: textual metadiscourse and interpersonal metadiscourse. Thus, he established seven types of metadiscursive markers. As illustrated by Figure 2, the first four types are textual (text connectives, code glosses, illocution markers, and narrators), whereas the remaining three are interpersonal (validity markers (hedges, emphatics, and attributors), attitude markers, and commentaries). 


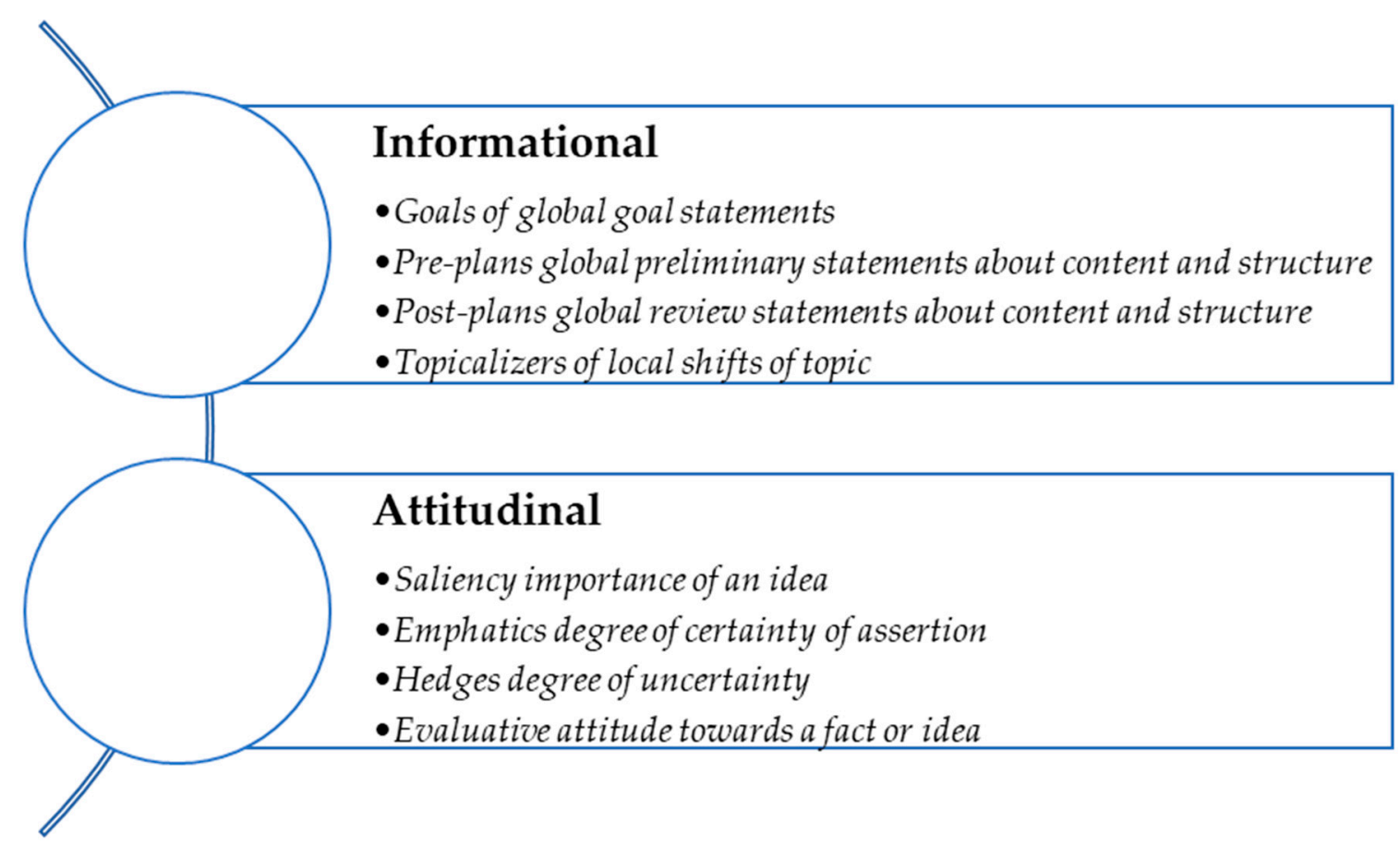

Figure 1. Crismore's (1983) model [10].

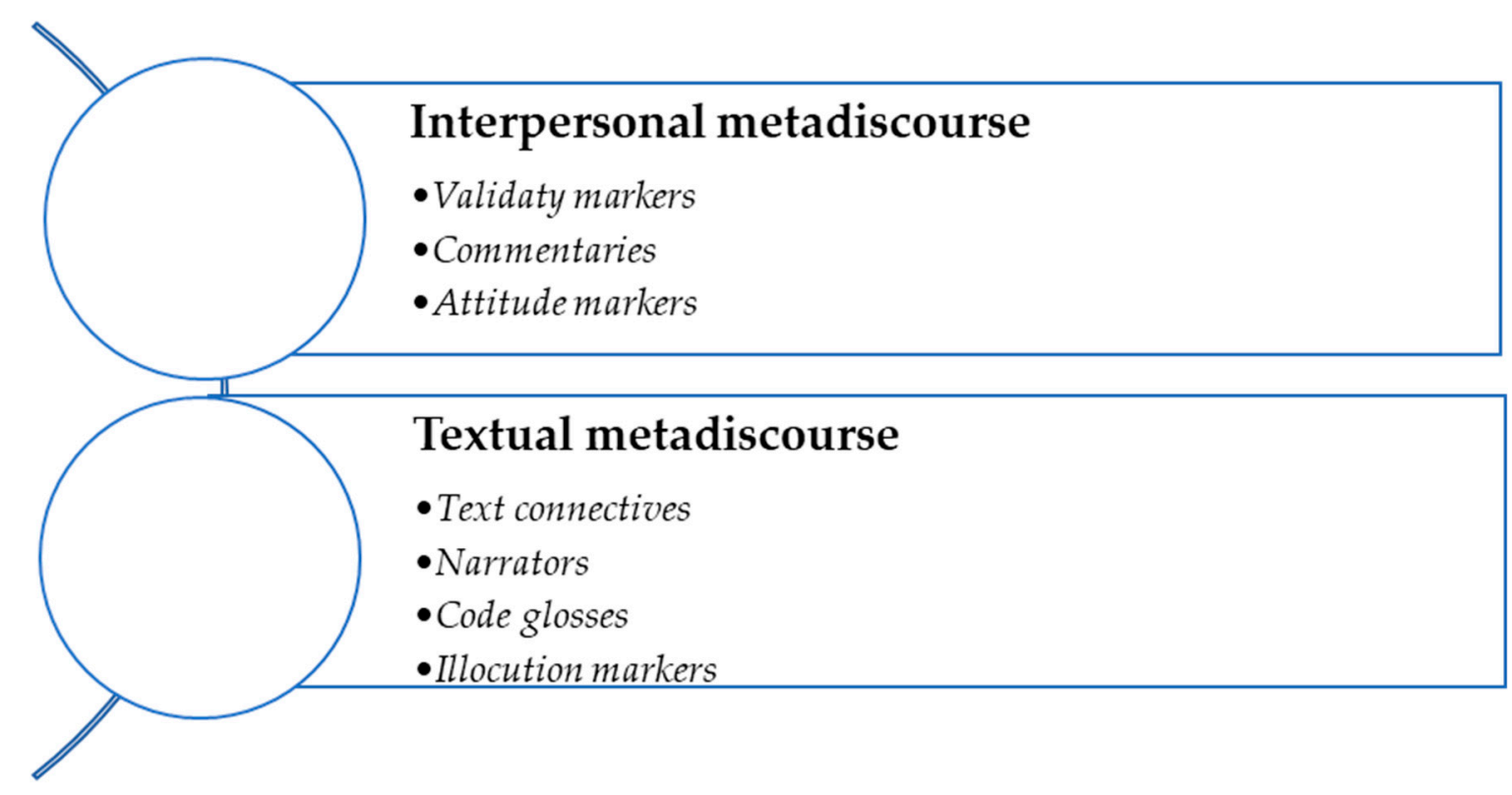

Figure 2. Vande Kopple's (1985) model [9].

Crismore and Farnsworth [14] added the category of "scientific commentaries", and Crismore et al. [15] divided metadiscourse into textual metadiscourse (text markers and interpretive markers) and interpersonal metadiscourse (hedges, certainty markers, attributors, attitude markers, and commentaries).

Focusing on academic texts, Hyland [16,17] proposed a modification of the classification in order to distinguish between textual and interpersonal metadiscourse. In addition, Hyland offered a more interpersonal perception of metadiscourse [5,18]. Studies following this approach reject the dichotomy of textual and interpersonal functions and develop a model tailored to texts characterised as an academic writing (Figure 3). This model presumes two macro-categories: Interactive, which helps guide the reader through the text, 
and interactional, which helps involve the reader in the text. Several authors have adapted

this model to fit the genre they study [19-22].

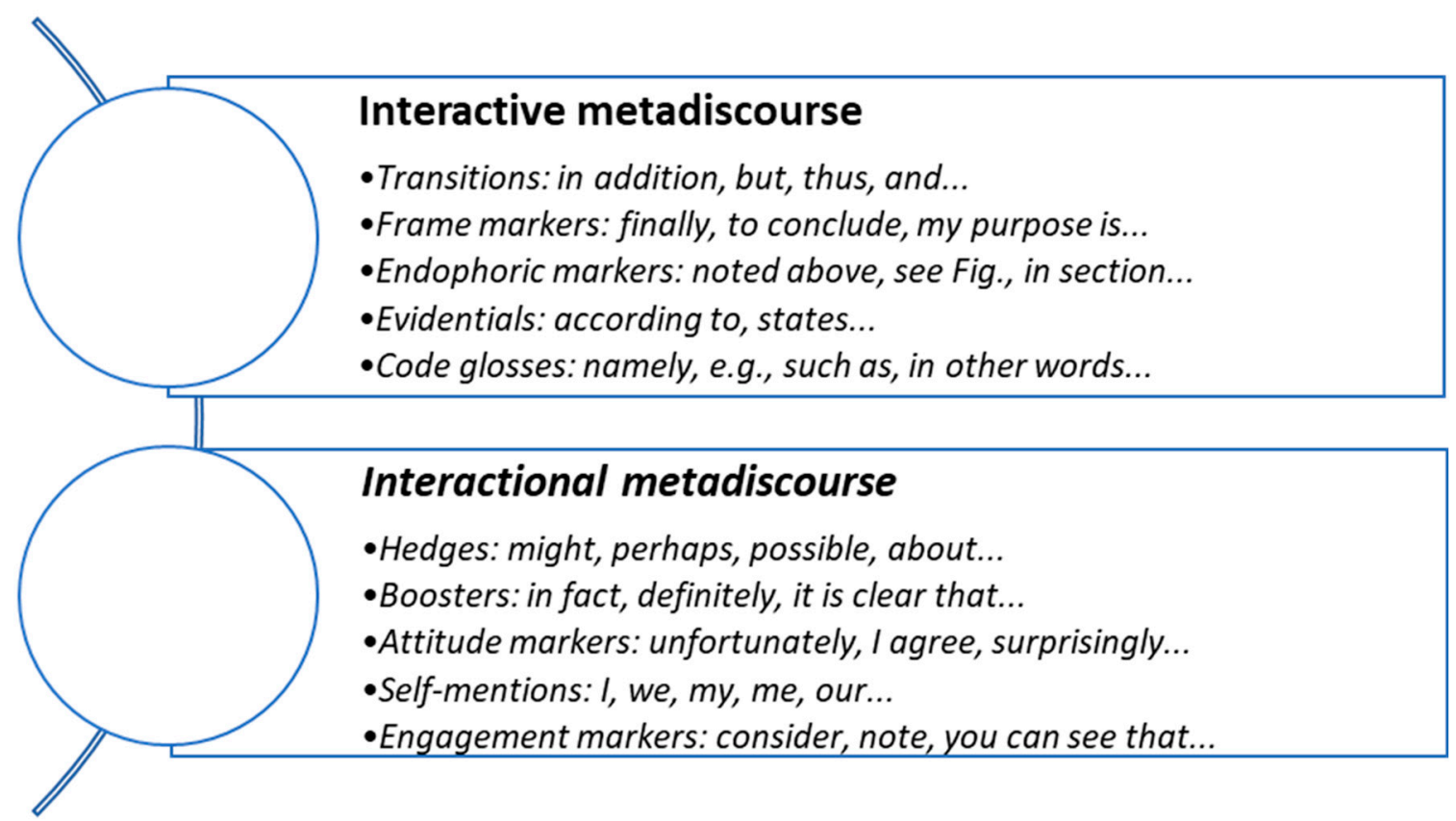

Figure 3. Categories of metadiscourse markers according to Hyland [5].

For a more in-depth discussion of the various approaches to both the theoretical framework and the categorisation of marker types see Wei et al. [11], who reviewed metadiscourse theories and models from the past 15 years.

\subsection{Research Objective and Hypotheses}

The aim of this paper was to determine whether the presence of metadiscourse markers in different texts follows a similar behaviour depending on the type of academic or nonacademic text in which it is found. In categorising the studies focused on academic writing we grouped these studies into three broad categories: (a) research articles, (b) university theses and dissertations, and (c) textbooks. In order to analyse non-academic texts, we used four categories: newspapers, Internet texts, tourist promotion materials, and texts that we denominated "oral texts". However, we did not make distinctions regarding the section of the text analysed (e.g., abstract, introduction, or conclusion), the subject matter (hard versus soft sciences), or the type of study, i.e., or whether the study was empirical or non-empirical.

This study aimed to compare the results obtained from other research works whose analysis of metadiscursive markers was grounded in Hyland's metadiscourse model. Comparisons of metadiscursive marker patterns within the same genre have been studied by several researchers, as has become evident in the referenced bibliography. Earlier studies $[16,18,23]$ have suggested that the use of metadiscursive markers in academic texts varies by linguistic and cultural communities and academic discipline.

The proposition that the use of metadiscursive markers can differentiate genres and text types to discern whether a generalisable pattern exists seems, to a certain extent, reasonable.

The hypotheses of the research are as follows:

Hypothesis 1 (H1): The data will be subject to individual variations, that is, differences will be found between different sections of the same genre within the same academic discipline. 
Hypothesis 2 (H2): The use of metadiscourse markers in academic and non-academic texts will be different according to the categories of Hyland's model.

Hypothesis 3 (H3): There will be similar behaviour of metadiscourse markers according to the selected classification of academic and non-academic texts.

\section{Methods}

\subsection{Corpus}

The corpus of this study comprised 334 documents obtained from the ScienceDirect and Scopus databases and Internet searches used to obtain book chapters. The selected texts are accessible with the University of Vigo library resources from the Spanish Foundation for Science and Technology.

The search criteria were the inclusion of the term "metadiscourse" in the text's title, abstract, or keywords. After selecting the documents, those that addressed discourse analysis or rhetorical analysis were excluded because these topics were not the focus of this study.

\subsection{Data Collection-Selection Criteria}

Considering the metadescriptive nature of this paper, rigorous article selection criteria were established to limit the number of studies and to obtain a sample that would guarantee comparability, thus facilitating the comparison of values among various types of metadiscursive markers in each document. The selection criteria used were the following:

1. Articles that adhered to Hyland's model were chosen because this model is the most frequently cited and most widely used in studies since the mid-2000s.

2. Articles that differentiated interactive and/or interactional metadiscursive markers were chosen.

3. Texts that used a classification system-based differentiation between transition, frame markers, endophoric markers, evidentials, and code gloss markers were included.

4. Texts that used a classification system-based differentiation between hedges, boosters, attitude markers, self-mentions, and engagement markers were included.

5. Documents that described and analysed the presence of markers in the texts were excluded when their corpus size was unknown because their data (number of appearances per 1000 words) could not be normalised prior to comparison.

Only the papers that belonged to one of the categories in Figure 4 were included.

The selected studies (44; see Appendix A) were categorised into two broad groupings, namely, academic texts and non-academic texts, with the following subcategories (Figure 4):

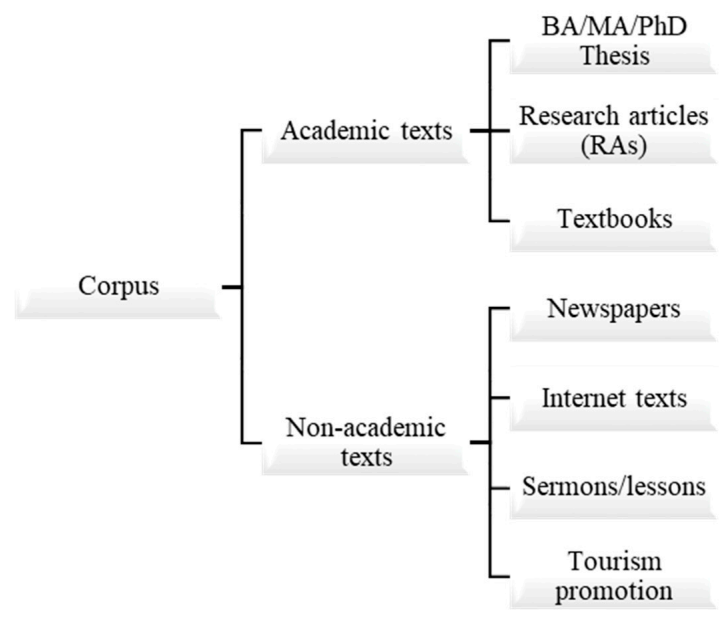

Figure 4. Textual genre classification. 
In the case of Bachelor's, Master's, and doctoral theses, we are aware that the former two should exhibit a lower degree of complexity than should the latter. Nevertheless, considering that the terms "thesis" and "dissertation" are used differently in academic contexts, we grouped these different documents together to obtain aggregate comparative averages. As Hyland [23] noted, theses are treated "differently in different countries and sometimes even in different universities in the same countries". Works that analyse research articles were also grouped together, regardless of whether those texts were article abstracts, conclusions, or bodies and whether they addressed topics related to the hard or soft sciences. Documents associated with oral presentations, such as lessons and sermons, were grouped together due to their expository nature. In the case of internet texts, all texts associated with wikis, the web, chats, and online forums were grouped together.

\section{Results}

\subsection{Data Analysis}

In this section, the values regarding the presence of metadiscursive markers obtained from the selected studies are compared and analysed. Our overall approach adhered to the distinction between interactive and interactional markers.

\subsection{Interactive Markers}

The research studies analysed for our meta-study showed that the linguistic and cultural context in which texts are written can impact the use of metadiscursive markers, even within the same genre. Below, we hypothesise about the possible causes of this variation.

As shown in Figure 5, academic texts (Master's theses, research articles, and textbooks) exhibited significant variation. Such variation may be owing to several factors. First, plotting the frequency of interactive markers as a function of text type showed that these markers are unevenly distributed.

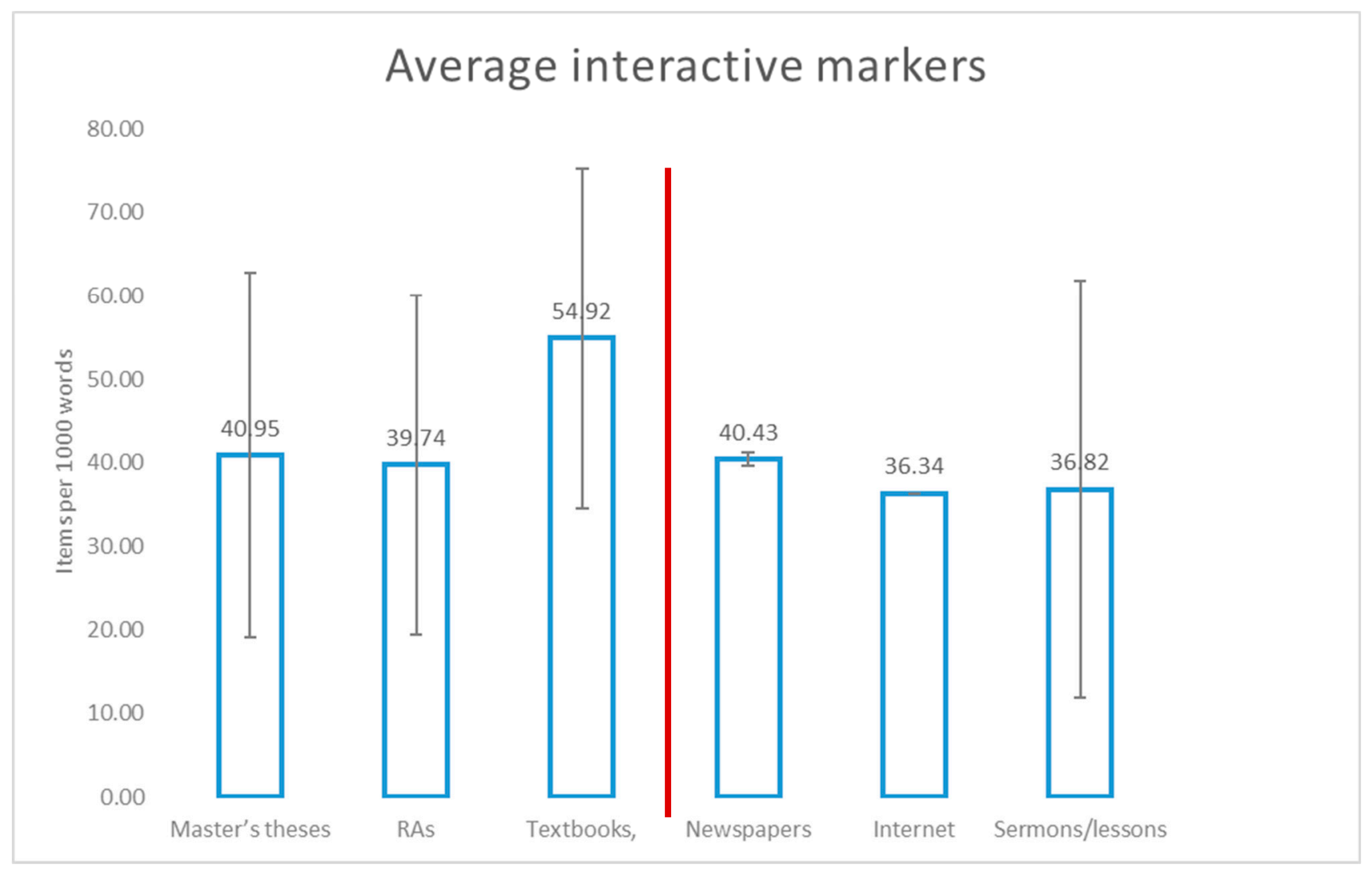

Figure 5. Interactive markers. Items per 1000 words (on average). Red line divides the academic from non-academic texts. 
The significant internal variability within each subcategory is also evident, particularly for theses. This high variability can be explained by differences in content and length and those resulting from the type of work entailed by the subject matter. Doctoral students use more interactive markers and engagement markers, and self-mentions appear much more frequently in doctoral theses than in Master's theses [23,24]. Likewise, we believe that the variation observed in the research articles fundamentally stems from the fact that marker usage may be determined by the discipline [5].

Second, if we focus on interactive markers, we can see that, on average, transitions/logical markers are the most frequently used. This result holds regardless of whether the analysed texts are theses, textbooks, or research articles or whether their disciplines are considered soft (social sciences) or hard (hard and technological sciences), though significant differences exist among several text types. Additionally, frame markers stand out in theses, and code glosses stand out in textbooks and research articles. Moreover, code glosses are the least-used marker type in theses (Figure 6).

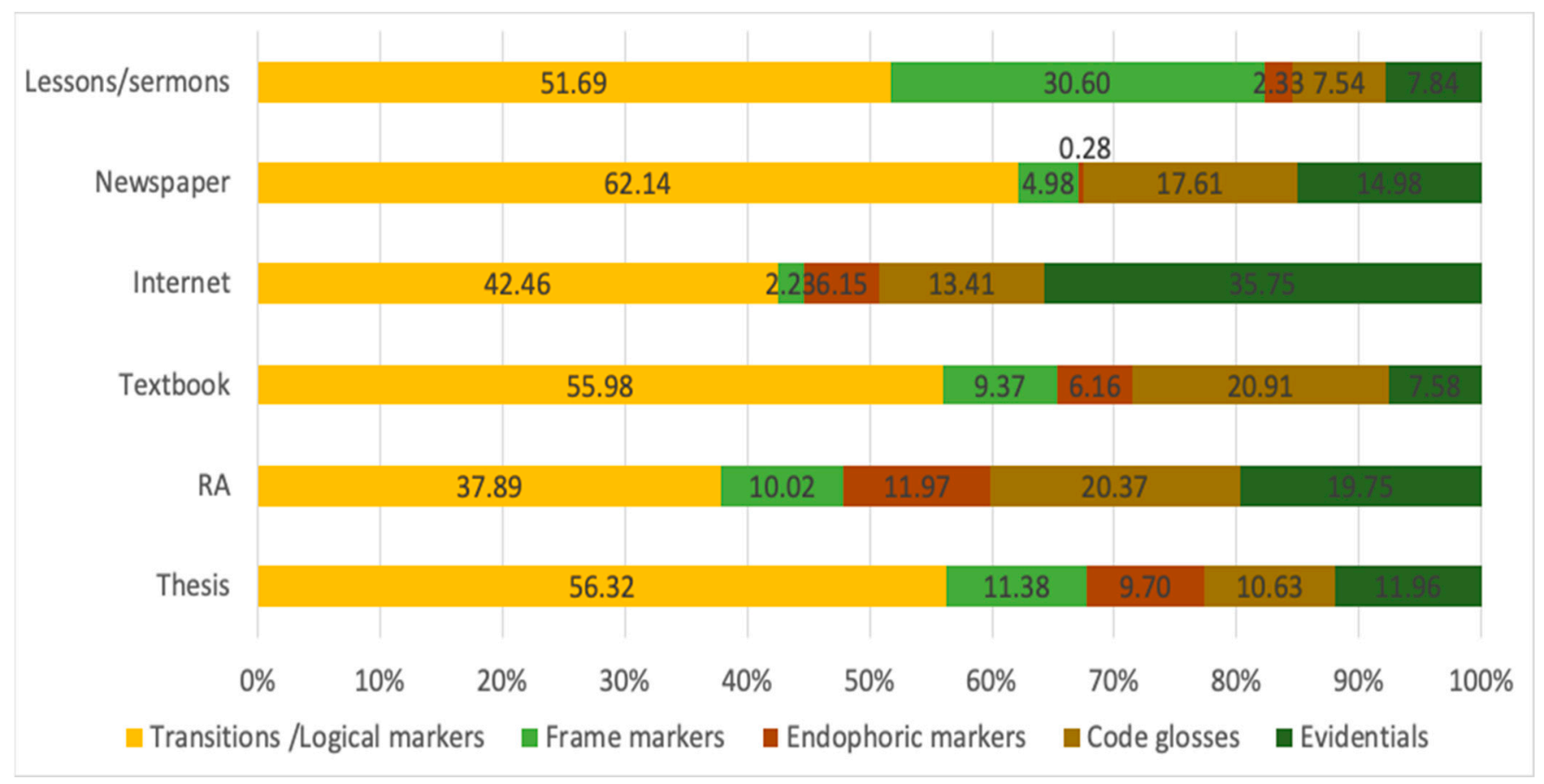

Figure 6. Average frequency of interactive markers per text type (items per 1000 words).

The greater influence of transitions/logical markers is evident in all texts, regardless of textual characteristics, as shown in Figure 6, which shows the percentage distribution of items per 1000 words.

A plethora of research studies have been conducted on the analysis of MD markers in different disciplines and different languages [25-29]. The overall results of these studies indicate that there is a strong association between the distribution of metadiscourse markers and the specific discipline.

Furthermore, a large proportion of evidentials is present in Internet texts (twice the percentage of other text types), likely because of the intertextual, multi-author, and social nature of Internet texts in terms of both their initial creation and their distribution, adaptation, and comment generation. The formation of relationships by referring to information in other parts of the text also follows logical patterns: Endophoric markers appear more frequently in long texts that require such references, such as academic texts or internet texts. However, endophoric markers are inconsequential in shorter texts (newspapers) and texts meant to be read aloud (sermons and lessons). Conversely, the more significant presence of 
frame markers in oral texts (sermons and lessons) is logical because the oral nature of such texts makes references to discourse shifts or text stages even more necessary.

\subsection{Interactional Markers}

As mentioned earlier, interactional markers, such as the elements that refer and relate to interactional practices [30], are used to establish speaking turns and linguistically comply with certain sociocultural conversation norms, among other functions. In this respect, interactional markers are clearly directed at the listener/reader, and such markers may arguably function to monitor message transmission [31]. In other words, interactional markers concern "the way that writers conduct interaction by intruding and commenting on their message" [5].

Figure 7 clearly illustrates that interactional markers are more widely used in nonacademic than in academic texts. Interactional markers are particularly prevalent in internet texts. The data on interactional markers also vary less than the data on interactive markers, as demonstrated by the corresponding standard deviations.

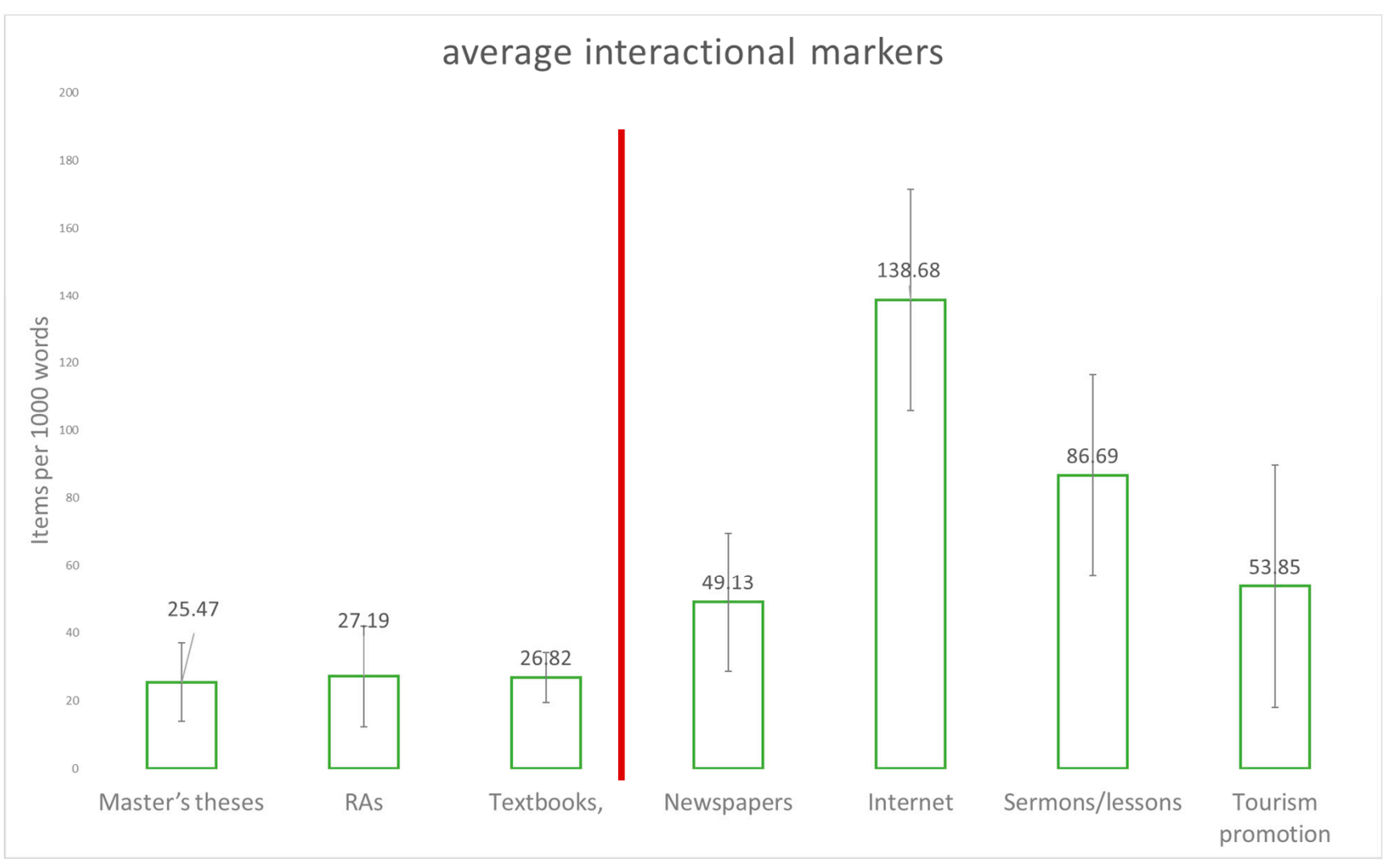

Figure 7. Interactional markers. Items per 1000 words (on average).

Additionally, hedges are the most frequently used marker regardless of the type of academic text or scientific field. Boosters constitute the next most frequently used marker in research articles (hedges and boosters combined account for $59.84 \%$ of markers per 1000 words), and engagement markers are the second most frequently used markers in theses (hedges and engagement markers together account for $62.34 \%$ of markers per 1000 words) and textbooks (with the two types combined representing $62.41 \%$ of markers per 1000 words). Self-mentions are the least frequently used markers. As illustrated by Figure 8, the data showing the frequency of the different interactional markers for these three text types are highly similar. 


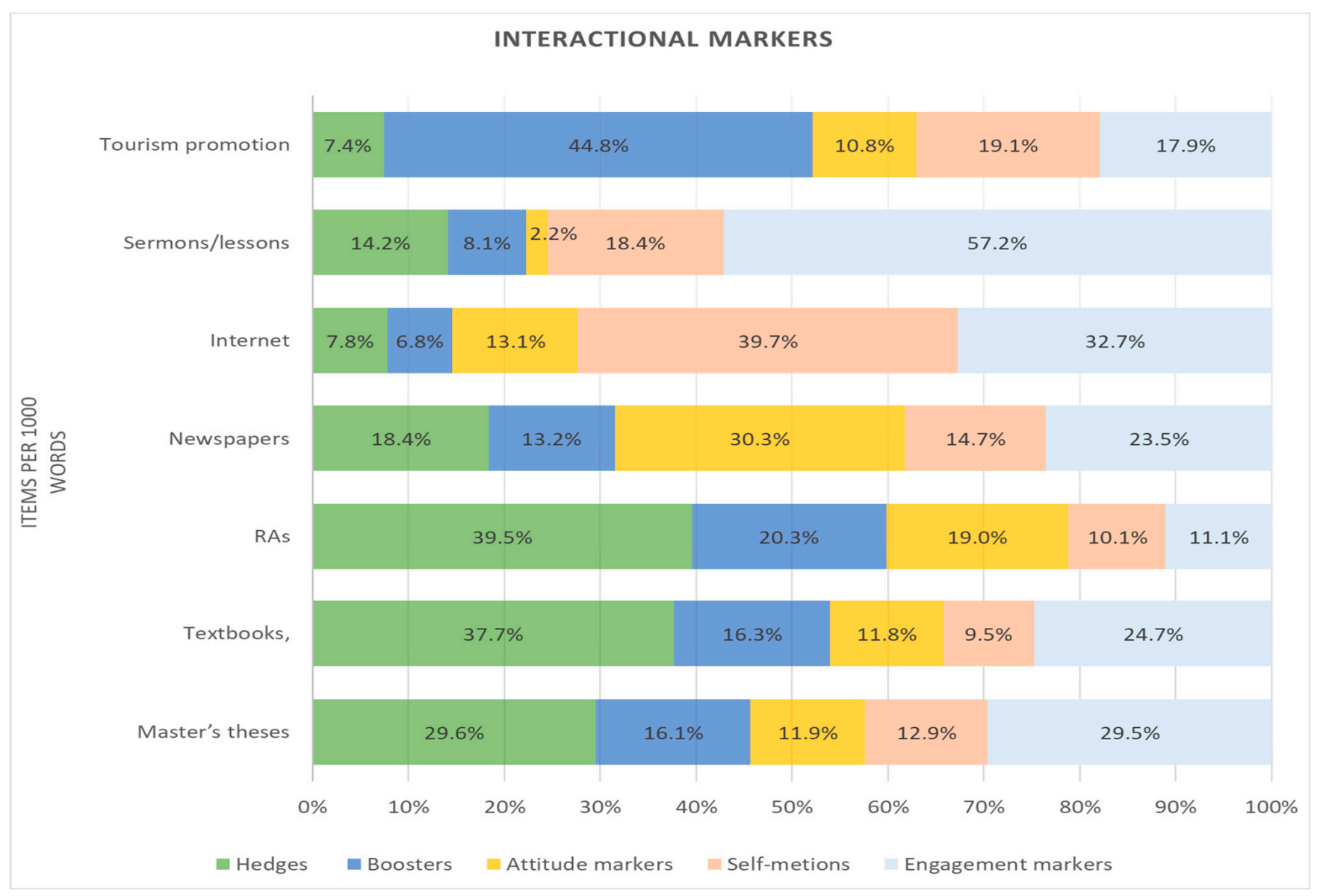

Figure 8. Interactional markers (percentage of appearance per 1000 words).

Hedges appear much less frequently in non-academic genres than in academic texts, with the number of hedges in non-academic texts being approximately one-third of that of academic texts. Several other significant differences between academic and non-academic texts in the use of interactional markers are apparent: Self-mentions and engagement markers.

The differences in the distribution of interactional markers that, broadly speaking, distinguish academic texts from non-academic texts are evident in Figure 8, which shows the percentage of appearances of each type of interactional marker for different text types. The percentage distribution of each marker type appears to not only differentiate academic from non-academic texts but also to typify each of the distinct types of non-academic texts analysed in this study.

Given that engagement markers function to engage listeners/readers and involve them with the text, this marker type is frequently used in both texts with an oral nature that are intended to convince listeners/readers (sermons and lessons) and Internet texts. In the case of the latter, we believe that the frequent use of engagement markers is linked to the aim to express opinions and convince individuals who visit websites and participate in online forums. Similarly, the significant presence of self-mentions in Internet texts likely stems from the intertextual, multi-author, and social nature of Internet texts in terms of both their initial creation and their distribution, adaptation, and comment generation.

The expression of opinions, which is common in newspapers, Internet texts, and tourism promotion materials because of their communicative intent, is reflected by a higher proportion of attitude markers. By contrast, attitude markers rarely appear in texts intended to convince or explain, such as sermons and lessons. Tourist promotional materials and texts of a more scholarly nature clearly exhibit a high percentage of boosters, which help emphasise certainty about the ideas expressed in these texts. 


\section{Discussion}

This article examined studies on metadiscourse in academic and non-academic texts. In categorising the studies focused on academic writing, we grouped these studies into three broad categories: (a) research articles, (b) university theses and dissertations, and (c) textbooks; we divided non-academic texts into four categories: newspapers, internet texts, tourist promotion materials, and texts that we designated as oral texts. Nevertheless, we did not make distinctions regarding the section of the text analysed (e.g., abstract, introduction, or conclusion), the subject matter (hard science versus soft sciences), or the type of study, that is, whether the study was empirical or non-empirical. Instead, we grouped these studies into three broad categories: (a) research articles, (b) university theses and dissertations, and (c) textbooks.

This study aimed to compare the results obtained from other research works whose analysis of metadiscursive markers was grounded in Hyland's metadiscourse model. Comparisons of metadiscursive marker patterns within the same genre have been studied by several researchers. Earlier studies have suggested that the use of metadiscursive markers in academic texts varies by linguistic and cultural communities and academic discipline.

Academic writing, particularly with respect to research articles, is possibly the most researched field. Nearly all studies indicated that the use of metadiscursive elements is influenced by such aspects as the context, field, genre, and the linguistic and cultural background of the author(s). Research has shown (Figure 9) a higher average of interactive markers compared to interactional markers in academic texts, independent of standard deviation. This aspect distinguishes academic texts from non-academic texts, in which interactional markers are predominantly in contrast. The standard deviations, however, indicate greater variability in academic texts than in non-academic ones, which, as earlier studies have indicated, reflects the influence of non-linguistic factors: the discursive community, language, subject matter, or the part of the texts that was analysed.

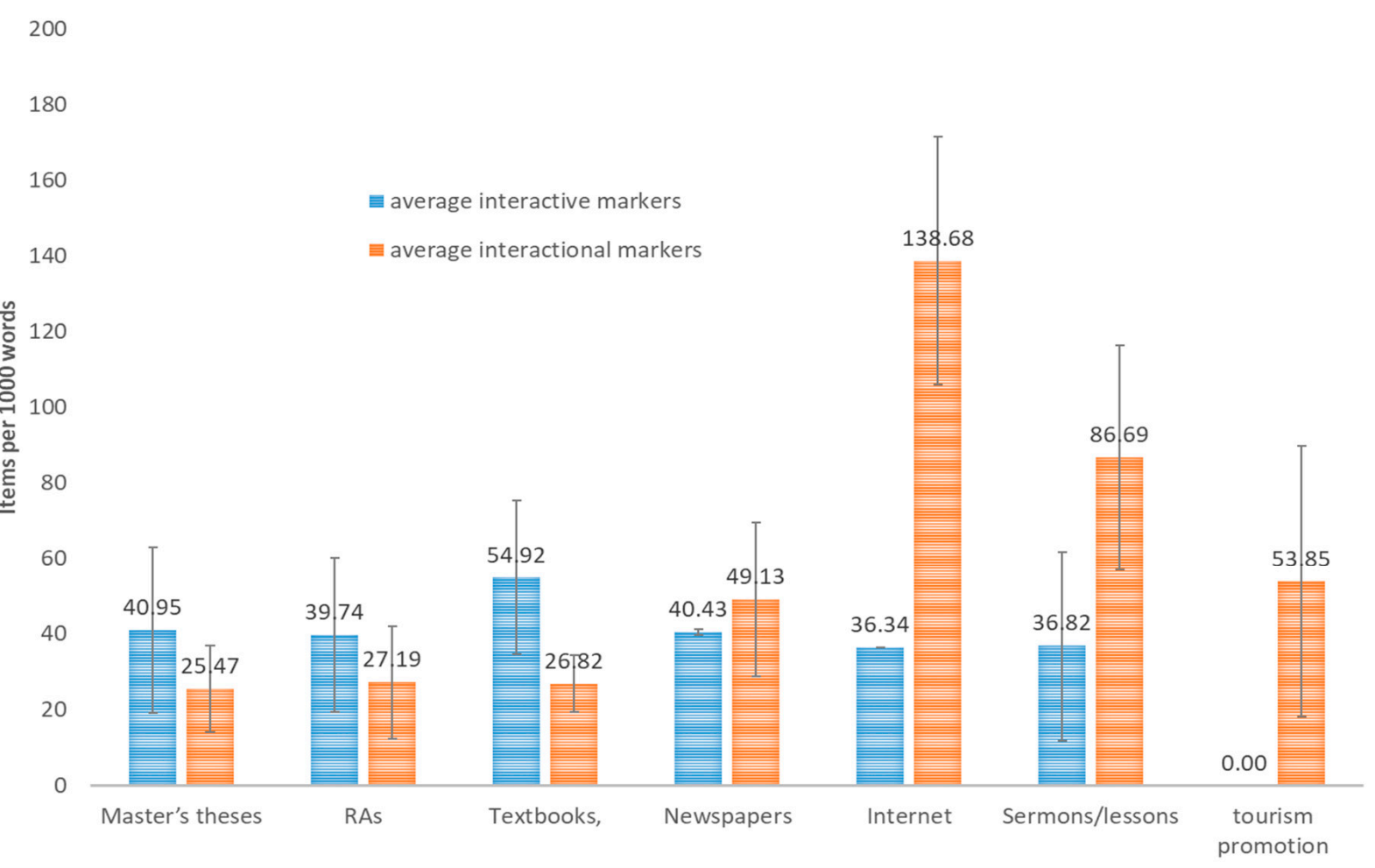

Figure 9. Interactive vs. interactional markers by textual genre (items per 1000 words). 
Academic texts feature a higher percentage of interactive markers than they do interactional markers, which is in stark contrast to non-academic texts. The unique characteristics of academic texts, particularly in terms of such features as the diversity of subjects they discuss and the diverse scientific and linguistic cultures that shape them, may explain the observed variability of the data. To this end, Hyland [16] singled out abstracts as an example. Abstracts are drafted to capture the attention of potential readers and therefore entail greater use of elements meant to strengthen reader interaction. Jimenez [20] suggested other reasons to explain the variability of marker usage in academic texts, including the writer/reader relationship, the degree of competition, the emphasis on authorial contributions, and the national scholarly culture.

All these explanations, among others, are acknowledged in the scientific literature $[5,15,19,21,22,27-31]$. As our metadescription showed, these justifications can also apply to non-academic texts, as Hyland noted on several occasions.

Internet texts show higher percentages of evidential marker use, derived from the intertextual, multi-author, and social nature of these texts in terms of both their initial creation and their distribution, adaptation, and comment generation. Endophoric markers likewise appear more frequently in academic texts and Internet texts because references to information in other parts of the text are necessary, yet this type of marker is nearly undetectable in texts that are briefer or are meant to be spoken aloud. This finding also seems consistent with the higher frequency of frame markers in oral texts, which tend to indicate discursive shifts and the stages of the text.

These variations in the usage of different markers can also be observed in the case of interactional markers (Figure 8). Academic texts revealed a high frequency of hedges (slightly less than $40 \%$ of all interactional markers per thousand words) and boosters (approximately $20 \%$ of all interactional markers per thousand words), compared to other types of markers, highlighting its use in research articles. The significant presence of these two marker types in academic texts may be owing to the need to establish logical relationships in complex texts and emphasise authorial certainty about the ideas expressed in the texts. Tourist promotion materials share this need to emphasise certainty, but the need to use emphasisers to convince and convey certainty is even greater in tourist promotion materials due to the social and economic influences involved in their development. The high percentage of boosters reflects this fact, as boosters can represent nearly $45 \%$ of the total interactional markers per thousand words.

When comparing oral texts intended to explain contents and ideas or convince listeners and/or readers (sermons and lessons) to other text types, the high frequency of engagement markers stands out, accounting for nearly $60 \%$ of interactional markers per thousand words. Conversely, the greater proportion of attitude markers in newspapers reflects the expression of personal opinions and attempts at persuasion, which is common for this text type [32-35]. Attitude markers, however, hardly appear in texts that are clearly intended to convince or explain. Meanwhile, tourist promotion materials feature few engagement markers, attitude markers, self-mentions, or mitigators. These results broadly coincide with the findings of previous studies [12,36-39].

Internet texts exhibit a high frequency of self-mentions and engagement markers (these two types constitute over $60 \%$ of all interactional metadiscursive markers per thousand words), and this seems to distinguish Internet texts from the other text types. However, differences exist based on the website and the culture in which the website is produced, as some researchers have noted [40]. In our data, such differences resulted in high standard deviations, which can be explained by the fact that Internet texts are highly dependent on the culture and discourse community of their intended audience and on the intertextual, multi-author, and social nature in terms of both their initial creation and their distribution, adaptation, and comment generation. As the author of [41] stated, the digital environment alters the message, the individual who issues that message, and the individual who receives it. According to Jensen [42], user participation is also characterised by a higher frequency of engagement markers (approximately 32\% per thousand words in our metadescription), 
though this percentage varies by the type of newspaper text analysed, which the author of [42] believed results from unplanned digital communication (i.e., comments) and the subject matter.

Although previous studies have detected metadiscursive similarities that allow journalistic genres to be considered as an entirety, various authors have identified several extratextual explanations that can justify the variability of the data regarding newspaper texts in our metadescription. These explanations include rhetorical and cultural preferences [43] that influence persuasiveness, the newspaper type [44], the subject matter [36,45], the newspaper section [6], and the columnist [46].

\section{Conclusions}

As noted in the introduction of this paper, metadiscourse is crucial to text creation because metadiscursive markers help establish relationships between the speaker/writer, the listener/reader, the sociocultural context, and the specific communicative situation. Metadiscourse guides how a message is interpreted because it also reflects the linguistic expression of sociocultural reality and the use of metadiscursive markers can differentiate genres and text types to a certain extent.

This study indicated that each type of text shows a preference for the use of one or more types of metadiscursive markers. These preferences seem to differ between text types, being especially visible in the case of interactional markers. One of the clearest findings of this study emerged when we presented the number of interactional versus interactive markers, as illustrated in Figure 10. The texts appear to be organised along the two axes in distinct zones.

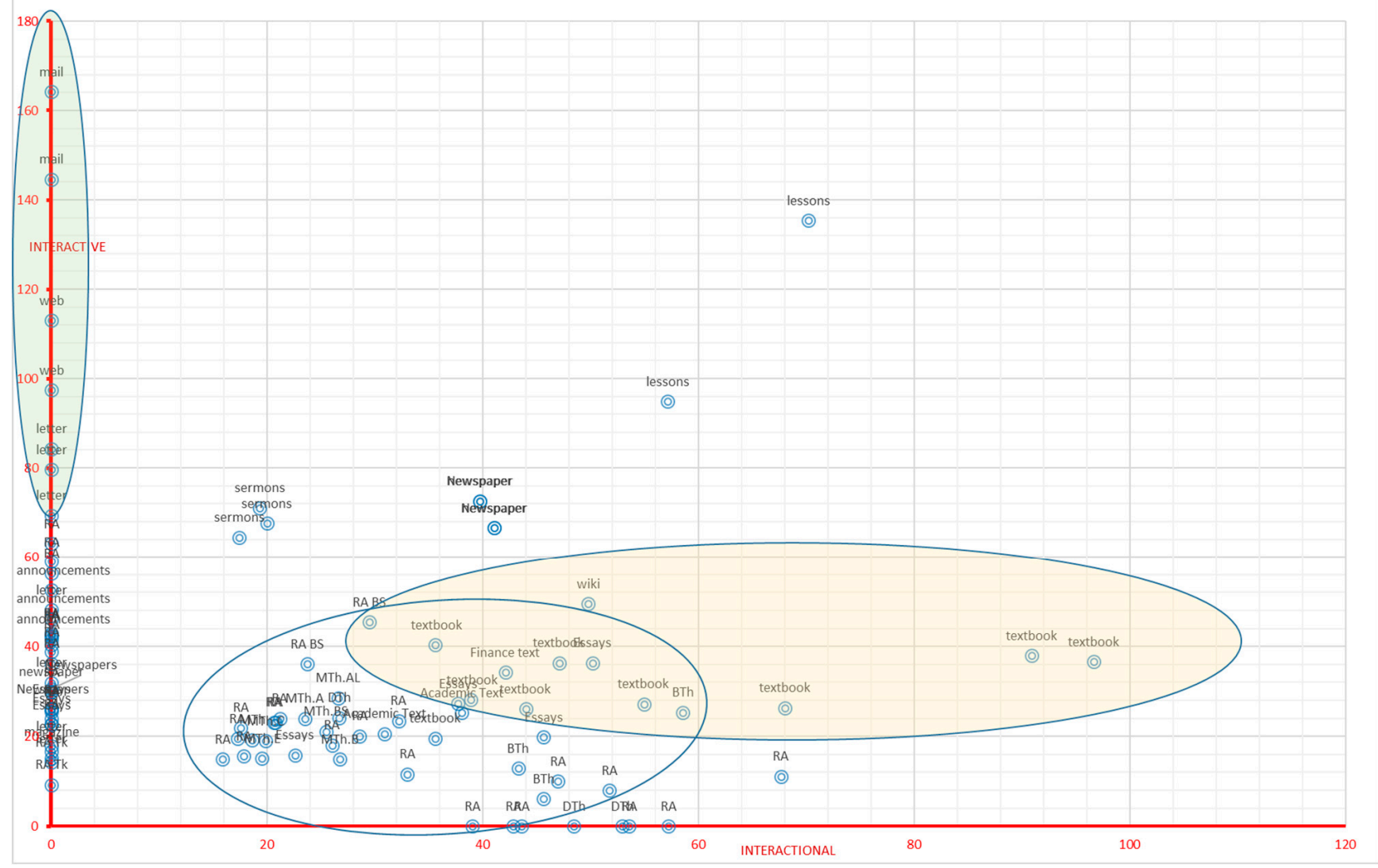

Figure 10. Distribution as a function of the presence of interactional vs. interactive markers. 
Despite our initial assumptions that the data found are subject to individual variations (e.g., the same text evaluated by another researcher), that there may be differences between different sections of the same genre within the same discipline of study, and that the addition or subtraction of some of the texts could have caused the results to vary significantly, a certain trend in the behaviour of the documents was observed, as seen in the previous paragraphs. This does not obviate the fact that, in order to know the individual behaviour of each document, it is necessary to study each specific case, given the heterogeneity in terms of category, subject matter, language, etc., and the authors' preference regarding the use of one or another marker.

The metadiscourse analysis was carried out using the list of words identified by Hyland in his book, but other potential options discovered by various researchers were also added to this list, as Hyland confirmed that this is an open category that allows researchers to contribute to the identification of metadiscursive elements. This reasoning explains why the level of specialisation of the target audience is relevant when characterising the text type since the members of a community share a common knowledge that the author of the text may take for granted [47].

Figure 9 showed that in the categories we selected and, more specifically, in academic texts, interactive markers tended to have a slightly higher mean value than interactional markers, regardless of the standard deviation, as can be seen in the different studies of the referenced researchers.

Similarly, it was clearly observed that in non-academic texts, practically the opposite occurred, the interactional mean values, in this case, being much higher, even tripled. The only case in which this did not occur is the grouped genre of journalism, these are similar and depend on the deviation. Moreover, in the case of tourism promotion, in which we did not find documents that meet the limitations, we established for the case of interactive markers that it is not possible to try to generalise as in the previous cases.

In response to the hypotheses

Hypothesis 1 (H1): The data will be subject to individual variation, that is, differences will be found between different sections of the same genre within the same academic discipline.

Hypothesis 2 (H2): The use of metadiscourse markers in academic and non-academic texts will be different according to the categories of Hyland's model.

Hypothesis 3 (H3): There will be a similar behaviour of metadiscourse markers according to the selected classification of academic and non-academic texts.

we found the following:

R1: We did not achieve sufficient uniformity in the number of studies to be analysed to ensure this statement. What was found is a very important variability among the studies of academic texts, so that this initial hypothesis could be accepted, as corroborated by many researchers.

R2: As can be seen in Figure 9, in non-academic texts, the use of international markers is very markedly increased compared to academic texts, even taking into account their variability.

R3: It was not possible to discern the behaviour according to the classification chosen. We have to take into account that within academic texts, the deviation is already important due to the different characteristics of the studies analysed.

If we adopt a more dynamic perspective that considers not only the direction of most of the data but also their dispersion and variability, our metadescriptive analysis confirms that these relationships are considerably more complex, and genre/text type boundaries are blurry and are constantly being validated by language users who belong to specific discourse communities. This complexity largely originates from the heterogeneous nature of the society in which these communities arise. In analysing certain characteristics of academic and non-academic discourse, we cannot neglect how relationships between 
communities are negotiated. In this sense, specific features of the discourse community reflect the unique characteristics produced through discourse, with the text understood as the relationships of resonance within an academic and/or a sociocultural community.

Our metadescription confirms this idea. For example, as we mentioned in our description of the data on interactive markers, the proportion of different marker types is linked to the text type. Internet texts show higher percentages of evidential marker use, which, as mentioned earlier, derives from the intertextual, multi-author, and social nature of these texts in terms of both their initial creation and their distribution, adaptation, and comment generation. Endophoric markers likewise appear more frequently in academic texts and internet texts because references to information in other parts of the text are necessary, yet this type of marker is nearly undetectable in texts that are briefer or are meant to be spoken aloud. This finding seems furthermore consistent with the higher frequency of frame markers in oral texts, which tend to indicate discursive shifts and the stages of the text. These variations in the usage of different markers can also be observed in the case of interactional markers.

We should also point out a limitation of this study that has to do with the corpus used in the different documents on which our metadescription was based. This limitation is threefold: (a) the number of studies used for our meta-analysis, which allows generalisation at this time but should nevertheless be increased in future studies; (b) the discrepancies in the size of the corpora of the studies analysed here; and (c) one of the most important limitations in the analysis of metadiscourse, both in this study and in others, lies in the knowledge of the list of words identified at first by Hyland, but which are also added to by researchers. It should be remembered that Hyland himself confirmed that this is an open category that allows contributing to the identification of metadiscursive elements since different words or grammatical turns of phrase can be used to communicate the same thing.

As several researchers have mentioned, future research could also extend this investigation to other domains to discern whether the new genres follow the same patterns as traditional genres. In order to a better knowledge of the behaviour of these metadiscursive markers and its correlation with the different discourse communities, it is necessary to conduct a more extensive and cross-cultural analysis based on bigger corpora that contain more textual genres.

Author Contributions: Both authors contributed equally to this work. All authors have read and agreed to the published version of the manuscript.

Funding: This research was funded by Consellería De Cultura, Educación e Ordenación Universitaria, Xunta De Galicia (Spain), grant numbers ED431C 2021/52 and ED481A-2018/275.

Data Availability Statement: Not applicable.

Conflicts of Interest: The authors declare no conflict of interest.

\section{Appendix A}

The following documents were used to categorise academic texts and to create the tables and figures in this study.

\begin{tabular}{cccccc}
\hline & Author-Reference & Year & Type of Text & Language & Corpus \\
\hline 1 & Abbas-Sultan [48] & 2011 & Research article & English/Arabic & $\begin{array}{c}\text { 70 discussion sections of research } \\
\text { articles: English (34) and Arabic (36); } \\
\text { discipline: Linguistics. } \\
\text { Civil engineering research articles } \\
\text { containing two sub-corpora of British } \\
\text { and Pakistani RAs, 45 in each }\end{array}$ \\
\hline
\end{tabular}




\begin{tabular}{|c|c|c|c|c|c|}
\hline & Author-Reference & Year & Type of Text & Language & Corpus \\
\hline 3 & Akbarpour [50] & 2014 & Research article & English & $\begin{array}{l}70 \text { research articles from economics, } \\
\text { humanities, life sciences, social } \\
\text { sciences, law, mathematics and } \\
\text { physical sciences, and medicine }\end{array}$ \\
\hline 4 & Alibabaee, [51] & 2016 & Textbook & English & $\begin{array}{l}\text { Six textbooks from three disciplines; for } \\
\text { each discipline, two textbooks were } \\
\text { selected: Mechanical engineering, } \\
\text { medicine, and psychology }\end{array}$ \\
\hline 5 & Alshahrani [52] & 2015 & $\begin{array}{c}\text { Doctoral } \\
\text { dissertation }\end{array}$ & English & $\begin{array}{l}80 \text { discussion and conclusion chapters } \\
\text { from linguistics doctoral dissertations } \\
\text { written in English by Arab and Native } \\
\text { English graduate students }\end{array}$ \\
\hline 6 & $\begin{array}{l}\text { Alyousef and } \\
\text { Picard [32] }\end{array}$ & 2011 & Wiki & English & $\begin{array}{c}\text { Four wiki discussion pages and } \\
\text { a report }\end{array}$ \\
\hline 7 & Alyousef [33] & 2015 & $\begin{array}{c}\text { Written } \\
\text { assignment }\end{array}$ & English & $\begin{array}{l}\text { The corpus consisted of three group } \\
\text { assignments written in English by a } \\
\text { total of } 10 \text { students on a finance course }\end{array}$ \\
\hline 8 & Cao and $\mathrm{Hu}[34]$ & 2014 & Research article & English & $\begin{array}{l}120 \text { RAs from the subfields of language } \\
\text { learning and teaching in applied } \\
\text { linguistics, education, and psychology }\end{array}$ \\
\hline 9 & $\mathrm{Fu}[35]$ & 2012 & Announcement & English & $\begin{array}{c}220 \text { JPs: Jobs column of the English } \\
\text { language newspapers the Daily } \\
\text { Telegraph and the Guardian and } \\
\text { three websites }\end{array}$ \\
\hline 10 & Fu-Hyland [36] & 2014 & Newspaper/magazine & English & $\begin{array}{l}\text { Two journalistic genres: } 200 \text { articles } \\
\text { from the magazines of the popular } \\
\text { science corpus (Scientific American, } \\
\text { New Scientist, and Science Magazine) } \\
200 \text { articles of opinion texts (the } \\
\text { Guardian, the Daily Telegraph, the Los } \\
\text { Angeles Times, and the New } \\
\text { York Times) }\end{array}$ \\
\hline 11 & $\begin{array}{c}\text { Gallego- } \\
\text { Hernández [37] }\end{array}$ & 2012 & Letter & French/Spanish & $\begin{array}{c}19 \text { letters from presidents of five } \\
\text { international societies; French/ } \\
\text { Spanish versions }\end{array}$ \\
\hline 12 & Ghadyani [38] & 2015 & Research article & English & $\begin{array}{l}90 \text { methods sections of English medical } \\
\text { research articles in English; three study } \\
\text { groups consisted of } 30 \text { articles selected } \\
\text { from ISI Native journals, ISI Iranian } \\
\text { journals, and non-ISI Iranian journals. }\end{array}$ \\
\hline 13 & Gholam [39] & 2011 & Research article & English/Persian & $\begin{array}{c}10 \text { research articles: English (5) and } \\
\text { Persian (5); discipline: } \\
\text { Computer engineering }\end{array}$ \\
\hline 14 & Hyland [17] & 1999 & Research article & English & $\begin{array}{c}21 \text { introductory coursebooks in } \\
\text { academic disciplines: Microbiology, } \\
\text { marketing, and applied linguistics; } \\
21 \text { research articles in academic } \\
\text { disciplines: Microbiology, marketing, } \\
\text { and applied linguistics }\end{array}$ \\
\hline 15 & $\begin{array}{l}\text { Hyland and } \\
\text { Tse [18] }\end{array}$ & 2004 & $\begin{array}{c}\text { Master's/doctoral } \\
\text { thesis }\end{array}$ & English & $\begin{array}{l}\text { 240:20 masters and } 20 \text { doctoral } \\
\text { dissertations each from six academic } \\
\text { disciplines: Applied linguistics, public } \\
\text { administration, business studies, } \\
\text { computer science, electrical } \\
\text { engineering, and biology }\end{array}$ \\
\hline
\end{tabular}


Author-Reference

16

Hyland [40]

2005

Research article

English

17

Ivorra [41]

2014

Web

Jensen [42]

2009

E-mail

Bachelor's thesis

English

$$
\text { Kan [54] }
$$

Khedri and

21

24

English/Spanish
Lee and Deakin [60]

Lee and Subtirelu [61]

Li and Wharton [62]

English

Lesson

English

English

\section{Corpus}

240 RAs in eight academic disciplines: Philosophy (30), marketing (30), sociology (30), applied linguistics (30), philology (30), electrical engineering (30), mechanical engineering (30), and biology (30)

100 business websites (50 from Spain and 50 from the US) of toy companies

46 e-mails from two persons in different professional roles

English abstracts of BA theses across three different disciplines (applied linguistics, material science, and electrical engineering)

20 articles from the Mustafa Kemal

University Journal of Social Sciences Institute: 10 Turkish language education and 10 Turkish literature Results and discussion sections of 16 RAs; disciplines: English language teaching (4), civil engineering (4), biology (4), and economics (4);

60 RA abstracts; discipline: Applied linguistics (30) and economics (30)

(20 research articles, 20 handbook chapters, 20 scholarly textbook chapters, and 20 introductory textbook chapters) in applied linguistics

60 newspaper editorials (written in English and Persian) from 10 elite newspapers in the US and Iran 200 Master's thesis results and discussion chapters: 100 written by L1 English students and 100 written by L1 Spanish students

75 argumentative essays written by US-based Chinese ESL and advanced L1 English university students, organised into three comparable corpora: 25 successful (A-graded) papers, 25 less-successful ESL

(B-graded) papers, and 25 successful L1 English (A-graded) argumentative essays

36 classroom lessons organised into two comparable corpora: $18 \mathrm{EAP}$

lessons from the L2CD corpus and 18 university lectures from the MICASE corpus

L1 Mandarin undergraduates' writing; disciplines: Literary criticism and translation studies 150 sermon manuscripts from the Church of England, the Baptist Church, and the Roman Catholic Church 


\begin{tabular}{|c|c|c|c|c|c|}
\hline & Author-Reference & Year & Type of Text & Language & Corpus \\
\hline 30 & $\begin{array}{l}\text { Martin- } \\
\text { Laguna [64] }\end{array}$ & 2015 & Essay & English/Spanish/C & $\begin{array}{l}\text { Three opinion essays, one in English, } \\
\text { one in Catalan, and one in Spanish, } \\
\text { talan } \\
\text { about three topics related to the school } \\
\text { ( } 22 \text { students) }\end{array}$ \\
\hline 31 & McGrath [65] & 2012 & Research article & English & Pure mathematics research articles (25) \\
\hline 32 & Mu and Zhang [66] & 2015 & Research article & English/Chinese & $\begin{array}{c}20 \text { journal articles in English and } \\
\text { another } 20 \text { in Chinese; discipline: } \\
\text { Applied linguistics }\end{array}$ \\
\hline 33 & Mur-Dueñas [19] & 2011 & Research article & English/Spanish & $\begin{array}{l}24 \text { research articles: } 12 \text { written in } \\
\text { English published in international } \\
\text { journals, and } 12 \text { written in Spanish } \\
\text { published in national journals }\end{array}$ \\
\hline 34 & Rubio [67] & 2011 & Research article & English & $\begin{array}{l}\text { Eight multi-authored articles; } \\
\text { discipline: Agricultural sciences }\end{array}$ \\
\hline 35 & $\begin{array}{l}\text { Salar and } \\
\text { Ghonsooly [68] }\end{array}$ & 2016 & Research article & English/Persian & $\begin{array}{l}20 \text { RAs from the knowledge } \\
\text { management discipline: } 10 \text { Persian and } \\
10 \text { English }\end{array}$ \\
\hline 36 & $\begin{array}{l}\text { Sorahi and } \\
\text { Shabani [69] }\end{array}$ & 2016 & Research article & English/Persian & $\begin{array}{l}40 \text { introductions of linguistics research } \\
\text { articles: } 20 \text { Persian and } 20 \text { English }\end{array}$ \\
\hline 37 & $\begin{array}{l}\text { Suau-Jiménez and } \\
\text { Dolón Herrero [70] }\end{array}$ & 2007 & $\begin{array}{l}\text { Promotion of } \\
\text { touristic services }\end{array}$ & English/Spanish & \\
\hline 38 & $\begin{array}{l}\text { Suau-Jimenez and } \\
\text { Labata Postigo [71] }\end{array}$ & 2017 & Touristic guide & Spanish/German & $\begin{array}{l}\text { Three different sub-corpora: Texts in } \\
\text { German as the original language, texts } \\
\text { in Spanish as the original language, } \\
\text { and texts in German as the } \\
\text { translated language }\end{array}$ \\
\hline 39 & Sultan $[48]$ & 2011 & Research article & English/Arabic & $\begin{array}{l}70 \text { discussion sections of linguistics } \\
\text { research articles written by native } \\
\text { speakers of English and Arabic }\end{array}$ \\
\hline 40 & $\begin{array}{l}\text { Tajeddin and } \\
\text { Alemi [72] }\end{array}$ & 2012 & Online forum & English & $\begin{array}{c}168 \text { comments made by } 28 \text { university } \\
\text { students of engineering via an } \\
\text { educational forum }\end{array}$ \\
\hline 41 & $\begin{array}{c}\text { Taki and } \\
\text { Jafarpour [73] }\end{array}$ & 2012 & Research article & English/Persian & $\begin{array}{l}120 \text { English and Persian research } \\
\text { articles in the two disciplines of } \\
\text { chemistry and sociology }\end{array}$ \\
\hline 42 & Tavanpour [74] & 2016 & Newspaper & English & $\begin{array}{c}\text { Sports news in newspapers (Iran Daily, } \\
\text { Tehran Times, Kayhan International, } \\
\text { the New York Times, and the } \\
\text { Washington Post) }\end{array}$ \\
\hline 43 & $\begin{array}{l}\text { Yavari and } \\
\text { Kashani [75] }\end{array}$ & 2013 & Research article & English & $\begin{array}{l}32 \text { applied linguistics research articles } \\
\text { (introduction, method, results, and } \\
\text { discussion/conclusion sections) }\end{array}$ \\
\hline 44 & $\begin{array}{l}\text { Yazdani and } \\
\text { Sharifi [76] }\end{array}$ & 2014 & Research article & English/Persian & $\begin{array}{l}30 \text { English and Persian news reports } \\
\text { (15 from each) }\end{array}$ \\
\hline
\end{tabular}

\section{References}

1. Halliday, M.A.K. Explorations in the Functions of Language; Arnold, E., Ed.; Cambridge University Press: London, UK, 1973.

2. Mauranen, A. But Here's a Flawed Argument: Socialisation into and through Metadiscourse. In Corpus Analysis: Language Structure and Language Use; Leistyna, P., Meyer, C.F., Eds.; Brill: Leiden, The Neatherlands, 2003; pp. $19-34$.

3. Larsen-Freeman, D.; Cameron, L. Complex Systems and Applied Linguistics; Linguistics, O.A., Ed.; Oxford University Press: Oxford, UK, 2008; p. 300.

4. Schiffrin, D.; Tannen, D.; Hamilton, H. Introduction. In The Handbook of Discourse Analysis; Blackwell: Oxford, UK, 2001; pp. 1-10.

5. Hyland, K. Metadiscourse: Exploring Interaction in Writing; Discourse, C., Ed.; Bloomsbury Publishing: London, UK, 2005.

6. Dafouz-Milne, E. The Pragmatic Role of Textual and Interpersonal Metadiscourse Markers in the Construction and Attainment of Persuasion: A Cross-Linguistic Study of Newspaper Discourse. J. Pragmat. 2008, 40, 95-113. [CrossRef] 
7. Ädel, A. Metadiscourse in L1 and L2 English; John Benjamins Publishing: Amsterdam, The Netherlands, 2006 ; Volume 24.

8. Hyland, K. Metadiscourse: What is it and where is it going? J. Pragmat. 2017, 113, 16-29. [CrossRef]

9. Vande Kopple, W.J. Some exploratory discourse on metadiscourse. Coll. Compos. Commun. 1985, 36, 82-93. [CrossRef]

10. Crismore, A. Metadiscourse: What It Is and How It Is Used in School and Non-School Social Science Texts; University of Illinois Library: Champaign, IL, USA, 1983.

11. Wei, J.; Li, Y.; Zhou, T.; Gong, Z. Studies on Metadiscourse since the 3rd Millennium. J. Educ. Pract. 2016, 7, 194-204.

12. Ädel, A.; Mauranen, A. Metadiscourse: Diverse and divided perspectives. Nord. J. Engl. Stud. 2010, 9, 1-11. [CrossRef]

13. Suau Jimenez, F. La Persuasion a Traves del Metadiscurso Interpersonal en el Genero Pagina Web Institucional de Promoción Turistica en Inglés y Español. In La Lengua del Turismo: Géneros Discursivos y Terminología; Calvi, M.V., Mapelli, G., Eds.; Peter Lang: Bern, Switzerland, 2011; pp. 177-200.

14. Crismore, A.; Farnsworth, R. Metadiscourse in Popular and Professional Science Discourse. In The Writing Scholar: Studies in the Language and Conventions of Academic Discourse; Nash, W., Ed.; Sage: Newbury Park, CA, USA, 1990.

15. Crismore, A.; Markkanen, R.; Steffensen, M.S. Metadiscourse in persuasive writing-A study of texts written by american and finnish university-students. Writ. Commun. 1993, 10, 39-71. [CrossRef]

16. Hyland, K. Disciplinary Discourses: Social Interactions in Academic Writing; Longman: London, UK, $2000 ;$ p. 240.

17. Hyland, K. Talking to Students: Metadiscourse in Introductory Coursebooks. Engl. Specif. Purp. 1999, 18, 3-26. [CrossRef]

18. Hyland, K.; Tse, P. Metadiscourse in academic writing: A reappraisal. Appl. Linguist. 2004, 25, 156-177. [CrossRef]

19. Mur-Dueñas, P. An intercultural analysis of metadiscourse features in research articles written in English and in Spanish. $J$. Pragmat. 2011, 43, 3068-3079. [CrossRef]

20. Suau-Jimenez, F. Quality translation of hotel websites: Interpersonal discourse and customer's engagement. Onomazein 2015, 32, 152-170.

21. Míguez-Álvarez, C.; Gonzalez-Varela, L.; Cuevas-Alonso, M. Identification of Metadiscourse Markers in Bachelor's Degree Theses in Spanish: Introduction of a Text Mining Tool. Span. J. Appl. Linguist. 2021, in press.

22. Míguez-Álvarez, C.; Cuevas-Alonso, M.; Saavedra, A. The relationship between phonological awareness and reading in Spanish: A meta-analysis. Lang. Learn. 2021. [CrossRef]

23. Hyland, K. Disciplinary interactions: Metadiscourse in L2 postgraduate writing. J. Second. Lang. Writ. 2004, 13, 133-151. [CrossRef]

24. Hyland, K. Metadiscourse: Mapping Interactions in Academic Writing. Nord. J. Engl. Stud. 2010, 9, 125-143. [CrossRef]

25. Abdollahzadeh, E. Poring over the findings: Interpersonal authorial engagement in applied linguistics papers. J. Pragmat. 2011, 43, 288-297. [CrossRef]

26. Dahl, T. Textual metadiscourse in research articles: A marker of national culture or of academic discipline? J. Pragmat. 2004, 36, 1807-1825. [CrossRef]

27. Jalilifar, A.; Alavi-Nia, M. We are surprised; wasn't Iran disgraced there? A functional analysis of hedges and boosters in televised Iranian and American presidential debates. Discourse Commun. 2012, 6, 135-161. [CrossRef]

28. Noorian, M.; Biria, R. Interpersonal metadiscourse in persuasive journalism: A study of texts by American and Iranian EFL columnists. J. Mod. Lang. 2010, 20, 64-79.

29. Zarei, G.R.; Mansoori, S. A Contrastive Study on Metadiscourse Elements Used in Humanities vs. Non Humanities across Persian and English. Engl. Lang. Teach. 2011, 4, 42-50. [CrossRef]

30. Kasper, G. Four perspectives on L2 pragmatic development. Appl. Linguist. 2001, 22, 502-530. [CrossRef]

31. Carter, R.; McCarthy, M. Cambridge Grammar of English a Comprehensive Guide: Spoken and Written English Grammar and Usage; University of Cambridge Press: Cambridge, UK, 2007.

32. Alyousef, H.S.; Picard, M.Y. Cooperative or collaborative literacy practices: Mapping metadiscourse in a business students' wiki group project. Australas. J. Educ. Technol. 2011, 27, 463-480. [CrossRef]

33. Alyousef, H.S. An Investigation of Metadiscourse Features in International Postgraduate Business Students' Texts: The Use of Interactive and Interactional Markers in Tertiary Multimodal Finance Texts; Sage Open: Newberry Park, CA, USA, 2015; Volume 5.

34. Cao, F.; Hu, G.W. Interactive metadiscourse in research articles: A comparative study of paradigmatic and disciplinary influences. J. Pragmat. 2014, 66, 15-31. [CrossRef]

35. Fu, X.L. The use of interactional metadiscourse in job postings. Discourse Stud. 2012, 14, 399-417. [CrossRef]

36. Fu, X.; Hyland, K. Interaction in two journalistic genres: A study of interactional metadiscourse. Engl. Text Constr. 2014, 7, 122-144. [CrossRef]

37. Gallego-Hernández, D. Metadiscurso y traducción en el lenguaje de los negocios: Estudio basado en corpus (francés-español). Rev. Electrónica Lingüistica Apl. 2012, 11, 13-24.

38. Ghadyani, F.; Tahririan, M.H. Interactive Markers in Medical Research Articles Written by Iranian and Native Authors of ISI and Non-ISI Medical Journals: A Contrastive Metadiscourse Analysis of Method Section. Theory Pract. Lang. Stud. 2015, 5, 309-317. [CrossRef]

39. Gholam, R.; Zarei, G.; Mansoori, S. Metadiscursive Distinction between Persian and English: An Analysis of Computer Engineering Research Articles. J. Lang. Teach. Res. 2011, 2, 1037.

40. Hyland, K. Stance and engagement: A model of interaction in academic discourse. Discourse Stud. 2005, 7, 173-192. [CrossRef] 
41. Perez, F.M.I. Cultural Values and their Correlation with Interactional Metadiscourse Strategies in Spanish and us Business Websites. Atlantis-J. Span. Assoc. Anglo-Am. Stud. 2014, 36, 73-95.

42. Jensen, A. Discourse strategies in professional e-mail negotiation: A case study. Engl. Specif. Purp. 2009, 28, 4-18. [CrossRef]

43. Khabbazi-Oskouei, L. Orality in Persian Argumentative Discourse: A Case Study of Editorials. Iran. Stud. $2016,49,677-691$. [CrossRef]

44. Le, E. Active participation within written argumentation: Metadiscourse and editorialist's authority. J. Pragmat. 2004, 36, 687-714. [CrossRef]

45. Sukma, B.P.; Sujatna, E.T.S. Interpersonal metadiscourse markers in opinion articles: A study of texts written by indonesian writers. Int. J. Appl. Linguist. Engl. Lit. 2014, 3, 16-21. [CrossRef]

46. Llopis, M.A.O. Krugman vs Garicano: Individual and Cultural Differences in the Rhetoric of Two Economic Op-Ed Writers; Hermes: Aarhus, Denmark, 2016; pp. 121-141.

47. Barton, D. Literacy: An Introduction to the Ecology of Written Language; Wiley-Blackwell: Hoboken, NJ, USA, 2007.

48. Sultan, A. A contrastive study of metadiscourse in english and arabic linguistics research articles. Acta Linguist. 2011, 5, $28-41$.

49. Ahmed, M.; Memon, S.; Soomro, A.F. An Investigation of the Use of Interactional Metadiscourse Markers: A Cross-Cultural Study of British and Pakistani Engineering Research Articles. Int. Res. J. Lang. Lit. 2016, 27, 61-85.

50. Akbarpour, M.; Sadeghoghli, H. The Study on Ken Hyland's Interactional Model in OUP Publications. Int. J. Lang. Linguist. 2015, 3, 266-270. [CrossRef]

51. Alibabaee, A.; Eslamizadeh, F.; Soleimani, F. A Contrastive Study of ESP Text Books and Content Books for Metadiscourse Markers: The Cases of Psychology, Medicine, and Mechanical Engineering. Theory Pract. Lang. Stud. 2016, 6, 886-893. [CrossRef]

52. Alshahrani, A. A Cross-linguistic Analysis of Interactive Metadiscourse Devices Employment in Native English and Arab ESL Academic Writings. Theory Pract. Lang. Stud. 2015, 5, 1535. [CrossRef]

53. Jin, X.; Shang, Y. Analyzing Metadiscourse in the English Abstracts of BA Theses. J. Lang. Teach. Res. 2016, 7, 210-215. [CrossRef]

54. Kan, M.O. The Use of Interactional Metadiscourse: A Comparison of Articles on Turkish Education and Literature. Educ. Sci. -Theory Pract. 2016, 16, 1639-1648.

55. Khedri, M.; Ebrahimi, S.J.; Heng, C.S. Patterning of interactive Metadiscourse markers in result and discussion sections of academic research articles across disciplines. Pertanika J. Soc. Sci. Humanit. 2013, 21, 1-12.

56. Khedri, M.; Ebrahimi, S.J.; Heng, C.S. Interactional metadiscourse markers in academic research article result and discussion sections. 3L: Lang. Linguist. Lit. 2013, 19, 65-74.

57. Kuhi, D.; Behnam, B. Generic Variations and Metadiscourse Use in the Writing of Applied Linguists: A Comparative Study and Preliminary Framework. Writ. Commun. 2011, 28, 97-141. [CrossRef]

58. Kuhi, D.; Mojood, M. Metadiscourse in Newspaper Genre: A Cross-linguistic Study of English and Persian Editorials. ProcediaSoc. Behav. Sci. 2014, 98, 1046-1055. [CrossRef]

59. Lee, J.J.; Casal, J.E. Metadiscourse in results and discussion chapters: A cross-linguistic analysis of English and Spanish thesis writers in engineering. System 2014, 46, 39-54. [CrossRef]

60. Lee, J.J.; Deakin, L. Interactions in L1 and L2 undergraduate student writing: Interactional metadiscourse in successful and less-successful argumentative essays. J. Second Lang. Writ. 2016, 33, 21-34. [CrossRef]

61. Lee, J.J.; Subtirelu, N.C. Metadiscourse in the classroom: A comparative analysis of EAP lessons and university lectures. Engl. Specif. Purp. 2015, 37, 52-62. [CrossRef]

62. Li, T.; Wharton, S. Metadiscourse repertoire of L1 Mandarin undergraduates writing in English: A cross-contextual, crossdisciplinary study. J. Engl. Acad. Purp. 2012, 11, 345-356. [CrossRef]

63. Malmstrom, H. Engaging the Congregation: The Place of Metadiscourse in Contemporary Preaching. Appl. Linguist. 2016, 37, 561-582. [CrossRef]

64. Martin-Laguna, S.; Alcon, E. Do Learners Rely on Metadiscourse Markers? An Exploratory Study in English, Catalan and Spanish. Procedia-Soc. Behav. Sci. 2015, 173, 85-92. [CrossRef]

65. McGrath, L.; Kuteeva, M. Stance and engagement in pure mathematics research articles: Linking discourse features to disciplinary practices. Engl. Specif. Purp. 2012, 31, 161-173. [CrossRef]

66. Mu, C.J.; Zhang, L.J.; Ehrich, J.; Hong, H. The use of metadiscourse for knowledge construction in Chinese and English research articles. J. Engl. Acad. Purp. 2015, 20, 135-148. [CrossRef]

67. Rubio, M.M.D. A pragmatic approach to the macro-structure and metadiscoursal features of research article introductions in the field of Agricultural Sciences. Engl. Specif. Purp. 2011, 30, 258-271. [CrossRef]

68. Salar, S.; Ghonsooly, B. A comparative analysis of metadiscourse features in knowledge management research articles written in English and Persian. Int. J. Res. Stud. Lang. Learn. 2016, 5, 15-27. [CrossRef]

69. Sorahi, M.; Shabani, M. Metadiscourse in Persian and English Research Article Introductions. Theory Pract. Lang. Stud. 2016, 6, 1175-1182. [CrossRef]

70. Suau-Jiménez, F.; Dolón Herrero, R. The Importance of Metadiscourse in the Genre 'Promotion of Touristic Services and/or Products': Differences in English and Spanish. In Languages for Specific Purposes: Searching for Common Solutions; Gálova, D.E., Ed.; Cambridge Scholars Publishings: Newcastle upon Tyne, UK, 2007.

71. Suau-Jimenez, F.; Labarta Postigo, M. El discurso interpersonal en la guía turística en español y alemán y su importancia para la traducción. Normas 2017, 71, 204-223. [CrossRef] 
72. Tajeddin, Z.; Alemi, M. L2 Learners' Use of Metadiscourse Markers in Online Discussion Forums. Issues Lang. Teach. 2012, 1, 93-122.

73. Taki, S.; Jafarpour, F. Engagement and stance in academic writing: A study of English and Persian research articles. Mediterr. J. Soc. Sci. 2012, 3, 157-168.

74. Farnia, M.; Tavanpour, N. Interactional Metadiscourse Markers in Sports News in Newspapers: A Cross-cultural study of American and Iranian Columnists. Philologist 2016, 1, 1-13.

75. Yavari, M.; Kashani, A.F. Gender-based study of metadiscourse in research articles' rhetorical sections. Int. J. Appl. Linguist. Engl. Lit. 2013, 2, 77-88. [CrossRef]

76. Yazdani, S.; Sharifi, S.; Elyassi, M. Interactional Metadiscourse in English and Persian News Articles about 9/11. Theory Pract. Lang. Stud. 2014, 4, 428-434. [CrossRef] 